\title{
Transfusion-Dependent Thalassemia in Northern Sarawak: A Molecular Study to Identify Different Genotypes in the Multi- Ethnic Groups and the Importance of Genomic Sequencing in Unst...
}

\section{ARTICLE in PUBLIC HEALTH GENOMICS · NOVEMBER 2014}

Impact Factor: 2.21

\section{READS}

40

2 AUTHORS:

Ashley Soosay

University Malaysia Sarawak

9 PUBLICATIONS 41 CITATIONS

SEE PROFILE
Henry Gudum

University Malaysia Sarawak

10 PUBLICATIONS 21 CITATIONS

SEE PROFILE 
Public Health Genomics
Public Health Genomics 2015;18:60-64

DOI: $10.1159 / 000368342$
Received: March 17, 2014

Accepted after revision: September 15, 2014

Published online: November 19, 2014

\title{
Transfusion-Dependent Thalassemia in Northern Sarawak: A Molecular Study to Identify Different Genotypes in the Multi-Ethnic Groups and the Importance of Genomic Sequencing in Unstudied Populations
}

\author{
Jin-Ai M.A. Tan ${ }^{a}$ Saw-Sian Chin ${ }^{b}$ Gek-Bee Ong ${ }^{e}$ Mohamed N. Mohamed Unni ${ }^{f}$ \\ Ashley E.R. Soosayc Henry R. Gudum ${ }^{d}$ Siew-Leng Kho ${ }^{a}$ Kek-Heng Chua ${ }^{a}$ \\ Jang J. Chen ${ }^{a}$ Elizabeth George ${ }^{g}$ \\ ${ }^{a}$ Department of Biomedical Science, Faculty of Medicine, University of Malaya, Kuala Lumpur, ${ }^{b}$ Institute of Social \\ Informatics and Technological Innovations, Departments of 'Paraclinical Sciences, and dPathology, Faculty of \\ Medicine and Health Sciences, Universiti Malaysia Sarawak, and ' Department of Paediatrics, Sarawak General

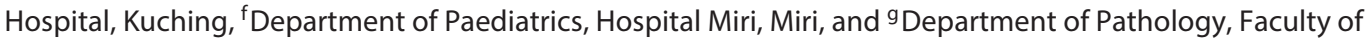 \\ Medicine and Health Sciences, Universiti Putra Malaysia, Serdang, Malaysia
}

\section{Key Words}

Chinese · Malays · Gene mutations · Indigenous groups ·

Sarawak · Thalassemia

\begin{abstract}
Background: Although thalassemia is a genetic hemoglobinopathy in Malaysia, there is limited data on thalassemia mutations in the indigenous groups. This study aims to identify the types of globin gene mutations in transfusion-dependent patients in Northern Sarawak. Methods: Blood was collected from 32 patients from the Malay, Chinese, Kedayan, Bisayah, Kadazandusun, Tagal, and Bugis populations. The a- and $\beta$-globin gene mutations were characterized using DNA amplification and genomic sequencing. Results: Ten $\beta$ - and 2 previously reported a-globin defects were identified. The Fil-
\end{abstract}

ipino $\beta$-deletion represented the majority of the $\beta$-thalassemia alleles in the indigenous patients. Homozygosity for the deletion was observed in all Bisayah, Kadazandusun and Tagal patients. The $\beta$-globin gene mutations in the Chinese patients were similar to the Chinese in West Malaysia. $\mathrm{Hb}$ Adana (HBA2:C.179G>A) and the $-a^{3.7} /$ aa deletion were detected in 5 patients. A novel 24-bp deletion in the a2-globin gene (HBA2:c.95 + 5_95 + 28delGGCTCCCTCCCCTGCTCCGACCCG) was identified by sequencing. Co-inheritance of a-thalassemia with $\beta$-thalassemia did not ameliorate the severity of thalassemia major in the patients. Conclusion: The Filipino $\beta$-deletion was the most common gene defect observed. Homozygosity for the Filipino $\beta$-deletion appears to be unique to the Malays in Sarawak. Genomic sequencing is an essential tool to detect rare genetic variants in the study of new populations.

\section{KARGER 125}

(c) 2014 S. Karger AG, Base

1662-4246/14/0181-0060\$39.50/0

E-Mail karger@karger.com

www.karger.com/phg
Jin-Ai M.A. Tan

Department of Biomedical Science, Faculty of Medicine

University of Malaya

Kuala Lumpur 50603 (Malaysia)

E-Mail maryanne@um.edu.my 